\title{
L'EX-SECTARI COM A PRODUCTE SOCIAL
}

\author{
Roser Sentís \\ DEPARTAMENT D'ANTROPOLOGIA SOCIAL I FILOSOFIA \\ UNIVERSITAT ROVIRA I VIRGILI. TARRAGONA.
}

\section{El perfil del "sectari potencial" és el d'una persona amb inquietuds espirituals}

La nostra societat ofereix nombroses i variades alternatives a totes aquelles persones que desitgen donar a la seva vida un sentit i una orientació espiritual. En un context legal de llibertat religiosa $\mathrm{i}$ d'associació $\mathrm{i}$ de llibertat d'expressió infinitat d'institucions (i fins i tot simples agrupacions) mostren i posen a la disposició de la població la seva versió i visió del com, el perquè $i$ la finalitat de l'existència humana i de la seva transcendència espiritual ${ }^{1}$.

Un gran ventall de doctrines religioses de les quals es desprenen postulats pràctics -la forma de representar-se la pròpia existència i la seva finalitat repercuteix en la forma en què aquesta s'autogestiona- conviuen en la nostra societat al costat de la catòlica que, si bé fa bastant temps que té l'hegemonia i compta amb la complicitat i el suport oficial i social, mai no ha tingut l'exclusivitat en el terreny religiós.

Dia rera dia les diferents institucions ofereixen a la societat el seu missatge religiós, espiritual i vital (tots tres aspectes estan lligats $i$ es presenten inevitablement plegats). I dia rera dia també, hi ha persones que els rebutgen ja d'entrada o després de conèixer-los i persones que els fan seus i passen a ser un membre més de la institució. Part d'aquests darrers, després d'un període més o menys llarg de temps, abandonen la institució per tornar a provar en una altra o, simplement, retornar a l'anteriorment abandonada.

Crec que és molt important fer notar això. Existeix la idea molt estesa que part d'aquestes institucions, a les quals se sol anomenar amb el nom despectiu de sectes (un terme utilitzat no amb intenció classificatòria o definitòria, sinó amb finalitat estigmatitzadora i desqualificadora) es nodreixen de deixalles socials, individus amb problemes o problemàtics, tarats físics i/o mentals, inadaptats, marginats socials o gent amb trastorns de conducta o comunicació... resumint: individus tots aquest suposadament ben predisposats envers aquestes institucions que representarien una

\footnotetext{
${ }^{1}$ Es evident que aquesta afirmació, sortint del pla tedric que ens parla de la representació ideal de la societz, per descendre al de la realitat dels fenòmens històrics concrets $i$ la vida quotidiana fa aigūes per tots costats. Encara que fos cert que totes les institucions per igual poguessin sense cap mena d'entrebancs portar a terme les seves activitats propagandístiques i organitzar-se d'acord amb els seus propis postulats, la societat, sense haver de recórrer a les lleis, reacciona d'una manera automàtica $i$ inconscient contra algunes d'aquestes institucions mitjançant mecanismes més o menys informals de control, desacreditació i desqualificació. A més, sempre pot recórrer al mateix corpus jurídic que en principi garanteix els drets de les persones i grups a pensar, expressar-se i organitzar-se lliurement per, al.legant la defensa d'agnestes mateixes persones, afegir esmenes i rectificacions a les lleis per a "casos especials" quan ja els mecanismes informals (premsa, opinió pública...) han creat un clima favorable a aquestes mesures. Agunes institucions juguen a casa, d'altres en terreny contrari. I l'àrbitre, en aquest cas la societat, no sempre és imparcial.
} 
alternativa a la societat ${ }^{2}$. Tot aixd̀ des del pressupòsit teòric que tota aquesta gent sent que no té o li és negat un lloc a la societat i s'hi sent marginada i injustament tractada. Penso que fariem bé de fugir d'aquest estereotip social. Potser sí que aquestes circumstàncies personals cal tenir-les en compte en casos concrets, però no és lícit generalitzar. I jo encara diria més: en aquests casos concrets és un factor que per si sol no resulta determinant. Si bé pot ser el detonant, dins el procés general no deixa de ser més que una circumstància acompanyant. Només qui busqui una sortida $i$ una orientació espiritual per a la seva vida acudirà a aquestes institucions o rebrà amb interès el seu missatge si li és donat a conèixer. Una persona catalogada socialment en qualsevol de les categories enumerades amb anterioritat (tarats, marginats, inadaptats...) però sense inquietuds espirituals no s'hi sentirà atreta. Potser s'entrenarà per als paraolímpics, s'apuntarà a un partit polític per lluitar pels seus drets, viurà al marge de les lleis i de la societat en general, reaccionarà violentament contra aquesta o part d'aquesta fent-se skin, posem per cas, o es limitarà a deixar passar la vida vençut per les circumstàncies... Tot això considerant que el pressupòsit teòric del qual es parteix sigui vàlid que ja és molt suposar perquè, malgrat l'etiquetatge social, aquestes persones poden sentir-se ciutadans absolutament normals o no viure la seva situació $i$ les seves circumstancies personals d'una forma traumàtica ni representar-se-les com a problemes. I, paral-lelament, persones catalogades socialment dins la més absoluta normalitat poden sentir que allo que els ofereix una d'aquestes institucions era el que havien estat buscant tota la vida i finalment han trobat... una vida, no cal dir-ho, caracteritzada per uns sentiments $i$ unes inquietuds espirituals intensos. Deixant de banda la qũestió de si realment han sorgit o no amb la finalitat d'acomplir aquest propòsit i sigui aquest el seu darrer objectiu o no, el que és prou clar i evident és que totes aquestes institucions donen una resposta a les necessitats espirituals de les persones que en formen part. Encara que en l'entrada i permanència en aquestes institucions poden concórrer molts factors, l'espiritual n'és l'únic decisiu.

\section{La ruptura amb la institució sectària està motivada per la pèrdua de fe en el model religiós que aquesta propugna}

D'entre les persones que han viscut l'experiència de formar part d'un d'aquests grups que propugnen diferents formes d'entendre l'existència humana i de gestió i perfeccionament del potencial espiritual dels individus $\mathrm{i}$, en un moment determinat, han decidit abandonar-lo o se n'han trobat fora, n'hi ha moltes, ben segur que la gran majoria, que no en fan gaires escarafalls.

Però part d'aquests homes i dones fan del moment de la ruptura amb la institució una data clau en la seva vida, convertint la seva existència posterior en un plany per la mala experiencia viscuda $i$, en alguns casos, en una croada contra tot allo que abans guiava i donava sentit al seu pas per aquest món. Es d'aquestes persones que tractarem i especialment deis seus discursos. Discursos que ens parlen de les institucions de les quals han format part i de la repercussió que, segons ells, l'experiència d'aquesta pertinença ha tingut sobre les seves vides i persones. I ho farem perquè, si bé constitueixen una minoria en relació al nombre absolut de persones que han tingut i tenen

${ }^{2}$ De fet aixd no és pas res de nou. El discurs és molt vell. També les persones que, en la nostra societat i dies del model normatiu i hegemònic (el catòlic) trien una opció de vida espiritual radical en el si d'una institució o estament especific han estat sempre víctimes d'estereotips i imatges socials més aviat negatives. En una conversa informal, per exemple, les raons per què una dona pren la decisió de vestir els hàbits no passen per explicacions de caire espiritual. Tot són insinuacions entorn a la incapacitat de la persona per poder exercir el que socialment és considerat el rol "normal" del seu gènere. Per dir-ho d'una manera, si es vol un xic barroera però clara i ajustada a la realitat, o es comenta que és més lletja que un pecat i com que no ha tingut a ningú que la volgués s'ha quedat per vestir sants $o$, si no té cap característica físiologica o biōigica que pugui contribuir a donar crèdit a aquesta afirmació, es fa recaure tot en suposades "degeneracions" o incapacitats sexuals. 
contacte $\mathrm{i}$ coneixement directe d'aquestes institucions i de la vida dins d'elles, és "a partir" ${ }^{\mathrm{m}}$ de la particular visió i versió d'aquesta minoria que es construeix la imatge social del grup, no pas a partir de la versió dels ex-membres no desqualificadors i molt menys encara de la dels membres en actiu. I això és tan més cert com més llunyana (culturalment, històricament, etc.) és la institució respecte a la societat que les "acull", i deixa de ser cert en el cas de la majoria de les institucions catòliques tradicionals, que historicament han cobert les demandes socials d'alternatives espirituals $s^{4}$.

Hem dit que el que ens interessa especialment de les persones que en un moment de la seva vida han pertangut a una institució religiosa i ja no en formen part és el seu discurs. Significa això oblidar d'altres aspectes tant o més interessants, com ara les causes que motivaren la ruptura amb la institució? En absolut. Són precisament els discursos d'aquests homes i dones els que ens permeten constatar que no existeixen causes reals i objectives que motivin la ruptura en el sentit de fets o circumstàncies que portin cap a una decisió radical de desvinculació.

Aquesta afirmació necessita d'una explicació perquè pot semblar força eixelebrada i contradictòria. Precisament tot aquell que hagi sentit parlar de la seva experiència a una d'aquestes persones pot objectar que es poden passar hores i hores esgrimint les causes que expliquen la ruptura amb la institució. Es cert. Però tots aquests fets, totes aquestes circumstancies que ens són presentades com a causes objectives no ho són pas... tot i que aquell o aquella que ens les presenta les senti com a tals. Les sent com a tals quan ja és fora i després d'un procés de recerca d'explicacions i respostes, però no podem pas afirmar que era així en el moment en què eren viscudes. Aixo no vol pas dir que s'hagin d'ignorar. Tot el contrari. Cal tenir-les molt en compte. Però no per explicar els motius que porten aquestes persones a trencar amb la institucio. Les causes exhibides en el discurs són representacions del passat des d'un present fiscalitzador; per tant, d'entrada són sospitoses de manca d'objectivitat i no serveixen per teoritzar i apuntar hipotesis sobre aquest passat. I amb aixo no vull pas dir que no s'hagin de tenir en compte o que no siguin rellevants. Jo defensaria més aviat tot el contrari: són un llibre obert, les pistes que ens permeten descobrir i reconstruir un "crim", el de la formulació i manteniment de l'estereotip del sectarisme com a fenomen de perillositat social $\mathrm{i}$ anul-lació de la llibertat individual. Cal tenir-les en compte i analitzar-les però com el que són: el contingut d'un discurs a posteriori', mai com una explicació objectiva del passat que ens permeti extreure'n dades per explicar-lo.

Després de llegir els Testimonis del ex-membres un s'adona que no es pot parlar de fets i circumstàncies concretes com a causes de la ruptura. I per tals entenc tot el que presenten aquestes

${ }^{3}$ En realitat no és "a partir de" sinó amb "l'ajut de". La precisió és important. En el primer cas el contingut d'aquests discursos generaria una imatge social; aquesta seria una consequủència directa dels discursos. Perd no és pas aixd el que succeeix. La imatge social sobre aquestes institucions ja existeix quan la persona dóna forma al seu discurs. Els discursos que els ex-membres elaboren sobre aquestes institucions inconscientment s'adapten a la imatge social existent prèviament $i$, com que reprodueixen els estereotips, son facilment utilitzables per farcir i enfortir la mateixa imatge social que els ha creat tal com són. El resultat és que es produeix una alimentació recíproca contínua. En realitat els discursos sóa més producte de l'adopció induĩda d'una imatge social per part dels individus que el producte d'una anàlisi crítica d'una experiència personal.

4 En aquest cas els discursos desqualificadors són una molt rara excepcí. Hi ha, això sí, acusacions puntuals. Tanmateix aquestes adopten una forma suau $i$, quan no es justifiquen o es disculpen recorrent a explicacions atorgades pel propi model s'emmarquen dins un discurs reformador. Aixd i el fet que la societat mai les impulsa $i$ les rep des d'una perspectiva reformadora fa que tinguin escassa transcendència social.

${ }^{5}$ I com a tals les analitzarem més endavant. Es força interessant $i$ revelador descobrir per què es trien uns fets i no uns altres, com s'expliquen i s'interpreten amb la intenció d'il.lustrar unes determinades acusacions i no unes altres en contra de la institució segons quina sigui aquesta i el perquè a unes institucions sistemàticament se li disculpen actituds i pràctiques que, també sistemàticament, serveixen per anatemitzar a unes altres. Els factors i mecanismes que influeixen $i$ condicionen la tria són força complexos $i$ interessants. 
persones als seus discursos: des de l'experiència de veure com d'altres membres són expulsats arbitràriament o la constatació que la institució està basada en un autoritarisme irracional, fins a sentir-se higiènicament abandonat per la dona (sic) o descobrir, horroritzat, que es troba dins d'una secta que anul-la la voluntat'. Penso que per entendre el perquè del rebuig a la institució i la posterior ruptura, el correcte fóra parlar alhora d'un canvi en la percepcí́ que es té d'aquesta i del que propugna com a doctrina i exigeix o recomana en el terreny de la praxi (l'ascesi) i d'un sentiment de desencís provocat per aquest canvi.

El motiu que determina les ruptures és un desencís que porta a una sensació de buidor espiritual i el que l'ha motivat, que tampoc pot considerar-se com un fet ja que és una nova forma de sentir i experimentar la propia situació espiritual i vital dins la institució. En aquest context d'esllavissament ja consumat d'un model de referència (en aquest cas religiós) els fets i circumstàncies presents al discurs no serien tant causes reals i objectives de ruptura, sinó més aviat fets triats per l'individu posteriorment, fets que es representa i sent (un cop fora, cal no oblidar-ho) com a causes d'aquest sentiment de desencís que li creava (o li crea encara) angoixa $i$ infelicitat $i$ l'ha portat a la ruptura. Molts cops aquesta tria de fets determinats que s'aniran exhibint mecànicament sense variacions respon en part a un intent de representar-se i presentar amb una cobertura de racionalitat tant la pròpia ruptura com un sentiment que un no acaba de saber d'on ha sortit, que no voldria sentir però que no pot evitar. I, no podent evitar-lo, necessita alguna explicacio; sovint resulta més difícil de suportar no saber de què o per què es pateix que el patiment en si mateix.

Però el que provoca la ruptura no és qualsevol sentiment d'infelicitat, sinб un d'especialment angoixant perquè està motivat pel desencis, la buidor i el desconcert provocats pel trontollament i esmicolament del model espiritual i vital que s'havia triat (alguns cops d'una manera molt madurada $\mathbf{i}$ després d'un procés de lluita interna per causa dels problemes que aquesta nova adscripció comporta... amb la famflia, la societat, la pròpia formació cultural, etc.), un model pel qual s'ha lluitat i d'acord amb el qual s'ha viscut durant molt de temps en alguns casos. Quan un individu sent que allo que un dia ho va ser tot en la seva vida ha deixat de tenir sentit per a ell, és facil que experimenti conflictes emocionals molt intensos. Acceptar que un canvi tan radical (la ruptura amb la institució i els seus postulats) pugui respondre al fet d'enfrontar-se a una decisió passada que en aquell moment no té un sentit pot resultar difícil. I, en aquesta situació, poder presentar a un mateix i als altres motius i explicacions tangibles, en el terreny dels fets contrastables i no en el dels sentiments i les idees simplement, ha de ser força reconfortant. I si aquestes explicacions remeten a valoracions negatives $i$ judicis de valors a la institució $i$ el model per ella propugnat, encara millor. I amb aixd no vull pas dir que els fets que se'ns narren i les acusacions contra les institucions siguin necessarriament totes falses, pures invencions al servei de mecanismes psicològics individuals (costa més acceptar que un ha triat malament, que s'ha equivocat, que adoptar el paper de víctima $\mathrm{i}$ dir que ha estat enganyat). Però el que sí es pot afirmar és que l'ésser humà tendeix a representar negativament allò que forma part del seu passat quan ha decidit construir un futur que sent necessitat de sentir radicalment diferent $\mathrm{i}$ millor. Hem de tenir en compte aquesta circumstància perquè repercuteix en el contingut del discurs que ens arriba i en la naturalesa del seu missatge.

Es evident que, en el temps que la persona ha estat membre de la institució (estem parlant des de casos d'un grapat de mesos fins a 30 i 40 anys), ha experimentat moments d'infelicitat, molts cops potser en viure fets i circumstàncies similars, equiparables 0 , fins $i$ tot, idèntics als que, en un altre moment, considerarà motius per trencar amb la institució $\mathrm{i}$ després presentarà com a

\footnotetext{
${ }^{6}$ Aquestes interpretacions i opinions són fruit d'un judici valoratiu del passat fet des d'un present hostil. Per tol aixð potser hauríem de ser una mica cautes a l'hora de procedir a una analisi partint únicament del que se'ns presenta, sense tenir en compte tot el que ha contribuit que ens sigui presentat així $i$ no de cap altra manera.
} 
causa de la ruptura. Per què en aquells moments la idea de la ruptura ni li passava pel cap? Els motius per superar aquests moments, justificar els fets i suportar les circumstàncies els trobava als mateixos postulats que la institució l'oferia, en el propi model religiós. I, en això, totes, si fa o no fa, parlen el mateix idioma: remeten a la imperfecció i la immaduresa espiritual dels seus membres que no els permet comprendre la necessitat de certes mesures "aparentment" injustes, al valor perfeccionador del sacrifici i al patiment en aquest món com a prova de fe de què se serveix el Senyor (o allo que en el model representi la perfecció absoluta) ${ }^{7}$. Aquest sentiment d'imperfeccio pot viure's de forma traumàtica però mai tant com ho seria la caiguda del model que guia tota una vida $\mathrm{i}$ atorga un sentit $\mathrm{i}$ una finalitat a la pròpia existència. Per aixo, mentre la persona senti que la institució l'ofereix una teoria de la naturalesa espiritual de l'home $i$ unes pautes per guiar la seva vida quotidiana $\mathrm{i}$ definir els seus projectes vitals satisfactories i convincents, acceptarà facilment les explicacions que aquesta dóna...també les que l'autoinculpen dels seus moments de tristor i dubtes d'acord amb la seva suposada imperfecció ${ }^{8}$. No hi ha cap problema, perquè el model també

7 -...doctrinalmente no tenía mucho contra ellos. Sabía que habían "metido la pata" en multitud de ocasiones pero existía esa explicación de "es que el esclavo fiel y discreto llegó a un mejor entendimiento; además no me parecian doctrinas sustanciales..." diu un ex-Testimoni. L'Opus Dei sembla especialment habil a utilitzar aquest tipus d'argumentacions. Veiem com ens explica una ex-numerària la seva entrada a l'Obra:*...Terminé los ejercicios espirituales en un mar de lágrimas y llena de angustia; enfrentaba el dilema de la posibilidad de terminar con mi futuro matrimonio dejando a mi novio, o de casarme sabiendo que no había respondido a la llamada de Dios y no había sido generosa con El...me dijeron en el Opus Dei que el sufrimiento era normal, casi un peso requerido por Dios como signo de purificacion...Todas estas ideas se entremezclaron en mi mente y en mi corazón y, al final, decidí que tenía que darle a Dios lo que me pidiera aunque fuera a costa del holocausto de mi futuro matrimonio y de herir profundamente los sentimientos de un hombre a quien quería con toda mi alma...". Més endavant encara afegeix: "...estaba totalmente convencida de que los superiores del Opus Dei knian razón...iEs que las mujeres que entramos al Opus Dei éramos todas bobas o nos manejaban como marionetas?. !No!...éramos cándidas y creimos a carta cabal que los superiores representaban la voluntad de Dios...nuestra postura era abandonarnos en manos de Dios, dando por supuesto que toda aquella doctrina procedía también de Dios y considerar que, si algunas cosas nos chocaban, se debía a nuestra ignorancia espiritual sobre la vida de santidad... Había muchas cosas que yo verdaderamente no entendía, pero siempre me salian al encuentro con que tenfa que pedirle a Dios adquirir el "buen espíritu" que predicaba el Padre...lo que yo pensaba interiormente es que mis valores tenía que ponerlos a los pies de Cristo y que este sacrificio mío, por la comunión de los santos, iria en beneficio de cuantas necesidades babia en la Iglesia.... . Les paraules d'una altra ex-membre de l'Opus encara són més significatives: "...Mira hacia arriba, ten visión sobrenatural"... ¿No lo entiendes?. No importa, no hace falta: "eso es fidelidad", aseguran...Así se puede comprender que haya tantos que se van...se niegan a ser autómatas. Pero... ¿acaso no explica esto también la permanencia de tantos? Dentro ¿por qué? Porque han aceptado, quizá inconscientemente, esta manipulación. Porque creen en ello....

Les institucions catoliques tradicionals (contra les quals a ningú se li acudiria llençar acusacions de sectarisme i rentat de cervell i manipulació) també bombardegen els seus membres amb aquestes explicacions. Seria aquest un cas un xic especial ja que, tot $i$ haver sortit de la institució, la persona no les rebutja ni les posa en dubte. La raó és prou seazilla: quan surt de la institució només està renunciant a una de les moltes opcions espirituals que un model religiós ofereix als seus membres $\mathrm{i}$ ell un dia tria, però això no comporta el rebuig del model; per tant, les explicacions continuen actives i fets $\mathrm{i}$ circumstàncies irregulars o que el van fer patir són justificades partint dels postulats del mateix model. Podem veure aix en les argumentacions d'un ex-monjo de Montserrat:"...L'any 1918, quan només tenia deu anys encara no complerts, vaig passar a estudiar al Seminari de Girona...no es pot pas dir que, en aquella edat, jo fes un acte conscient, llinre o responsable...Però no és menys cert que les maneres que Déu utilitza per cridar els seus elegits són tan variades com inescrutables. Alguns han estat cridats en edat adulta...I d'altres bo han estat en minoria d'edat, com Samuel $i$ tants altres sants, sense saber massa bé el que feien...".

${ }^{8}$ Mentre el model s'accepti tot es viu i es jutja (s'experimenta $i$ s'interpreta) partint d'aquest i el fet de no scabar d'entendre quelcom s'imputa a la pròpia imperfecció o limitació. Evidentment, en el discurs dels ex-sectaris molt sovint aquest comportament s'interpreta com una conseqũència del suposat procés sofert de rentat de cervell i programació. Veiemho:

Un ex-membre de GNOSIS diu: "...te lo pintan todo tan bien, y a poco a poco, que no le sabes ver la parte critica, $i$ no?. Simplemente vas admitiendo todo lo que te van diciendo y vale. Yo lo veía algunas algunas cosas un tanto abstractas pero yo pensaba: bueno, con el tiempo iré entendiendo lo que verdaderamente es esto..... Més clar resulta encara el que explica la mateixa persona, parlant d'un tema concret que no acabava de tenir prou clar ("lo de las relaciones sexuales no

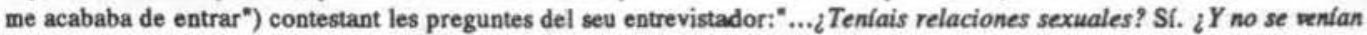


li ofereix la possibilitat de superar la imperfecció, d'avançar espiritualment per arribar a una més gran comprensió. Allò que resulta realment traumàtic és acceptar la imperfecció del model perquè aquests (que per definició es consideren perfectes com a reflex i obra que són de la perfecció absoluta: de Déu, la Veritat, la Saviesa etc.) no consideren aquesta possibilitat d'autocrítica i reforma, la possibilitat d'experimentar un procés de perfecció a nivell d'institució i de postulats teòrics. O val o no val, i si un decideix que no li val, això deixa un buit.

Quan la visió que ofereix el model religiós de la institució sobre l'existència humana ja no convenç, deixen de servir les seves explicacions (també la que fa referència a la imperfecció dels membres "menys docils " o amb menys fe). El marc de referència es va esquerdant fins a caure tot fet miques. Paral-lelament, i com a consequència d'aixo, la persona experimenta un profund sentiment de desencís que el pot portar a la ruptura amb la institucio $\sigma^{\circ}$. L'experiència de la quotidianeitat adaptada als postulats de la institució comença a pesar massa i a buidar-se de sentit $^{10}$. Els fets $s^{\prime}$ interpreten ara des d'una nova perspectiva a causa d'una nova actitud intel-lectual i vital envers la institució i el model religiós que propugna.

Un cop fora de la institució, fets i circumstàncies fins llavors irrellevants o que no eren pas viscuts de forma traumàtica per la persona, o eren racionalitzats d'acord amb el model religiós de la institució, són presentats per ella com a causes de la decisió de la ruptura. En el discurs posterior aquests fets passen a ser descrits com les claus que han permès l'individu "adonar-se d'on era, el

ajustando en nada a lo que se decia alli? Si, se venian ajustando. ${ }_{2} Y$ que tal iba? Bien, bien, lo tenia yo bastante asumido...llegué a concienciarme bastante y a centrarme bastante en lo referente a eso...con la otra novia...habiamos tenido rolaciones sexuales y hablamos hecho normal...con la chica esta ise plantearon así? pues bueno, lo empecé a asumir. Yo es que, como me lo habian metido alli, pues lo tenía claro...*. Un ex-Testimoni de Jehovà ho veu així: "...en ocho años que be estado con ellos hemos visto muchas cosas, pero, como teniamos el cerebro lavado, creiamos que era la verdad... I una xiqueta que va passar per un pis de I'Opus recorda així la seva experiència: "...et fan un món tan perfecte... T'ailles tant del món exterior...estàs més bé, és més eòmode, que no estar fora lluitant...tot té solució, 6́s que em pots preguntar tot el que vulguis que jo et donaré la solució....aixd té les seves repercussions en les actituds dels membres davant circumstàneies coneretes com ella mateixa explica...bi ha pares que segons elles estaven molt ben formats...(però) con que els meus pares no estaven formats, el millor és que no anés gaire, a més deien que els pares...t han donat la vida però tu no els deus res a ells...Es que entre que et van menjant el cap i que les coses les fan anar com ells volen que vagin, al final acabes pensant que bueno, que potser és veritat que els pares t'han donat la vida i ja esta.... (fora de la institució en el moment en què ho explica), com en una situació dificil reacciona no rebutjant el que el fa patir sinó acceptant-lo d'acord amb els postulats del model religiós i superant-lo i consolant-se amb els mecanismes que aquest l'ofereix:"...jo em trobava completament esfondrat, sense ideals ni iniciatives; sense certituds ni seguretats. I el més dolorós d'aquella situació era que jo no podia fer absolutament res per canviar-la o remiar-la. Convençut que el meu deure era de perseverar fos com fos en la meva vocacio, mai no se m'acudf de fet marxa earera...el perill més greu, en aquelles circumstàneies, era el de la desesperació. I si vaig evitar d’ésser engolit per ella, només va ser per la gràcia de Déu al qual vaig abandonar-me sense reserves, disposat a aguantar tot el que ell em permetés.... Abandonar-se a Deu $\mathrm{i}$, com explica més endavant, posar-se sota la protecció de sta Tereseta de Lisieux que, com ell, suporth les injustícies dels seus companys resignadament oferint el seu sacrifici al Senyor $i$ aceptant-les com a voluntat divina.

9 En alguns casos, però, el procès pot ser invers, produint-se primer el trencament amb la institució $\mathrm{i}$ més endavant la desintegració del model que aquesta propugna. Estem parlant, evidentment, de ruptures no voluntaries, entenent per aixd les forçades des de I'exterior. En aquests casos (quan la persona és objecte de "rescats" i posteriors "desprogramacions") el canvi d'actitud envers la institució i els seus postulats no és producte d'un procés de reflexió personal sinó d'un procés de replantejament manipulat de la pròpia experiència induit per terceres persones.

${ }^{10}$ Les paraules d'aquest ex-Testimoni són prou il.lustratives: "...Esa doctrina ya no nos decía nada ni a la meate ni al corazón. Ya nuestras ideas no coincidían con la fe de los otros miembros de la secta...Comenź entonces nuestra hucha interna que sólo quien la ha pasado puede saber lo que es. Sabiamos que no estábamos en la verdad ipero habiamos pasado tantos años con los Testigos!...que nos era muy dificil desechar de la mente esas doctrinas. Por tres veces intentamos dejarlo todo $\mathrm{y}$ no pudimos, pues siempre volvíamos de nuevo a ellos...". Aquest home, que en un altre moment parla de rentats de cervell $\mathrm{i}$ reprodueix tots els topics acusatoris contra la institució abandonada, amb aquestes paraules ens permet descobrir que la causa de la ruptura en realitat és més que res un problema de fe, de manca de fe, que el que la provoca és l'esmicolament del model religios, aix́́ com el decensis i buidor espiritual que això crea. 
que estaven fent amb ell i de la necessitat de sortir". Els fets en si mateixos, però, són el detonant de la decisió de desvinculació tan sols després d'aparèixer en l'individu aquesta nova percepció i interpretació fora de l'ortodòxia del módel institucional. Hi ha persones que romanen quaranta anys en el si d'una institució i els mateixos fets (mesures, postulats teòrics, pràctiques...) experimentats el darrer any i que el porten a la ruptura els ha viscut durant els altres 39 anys i, o li han passat desapercebuts o els ha justificat o fins $i$ tot defensat.

El veritable motiu de ruptura queda clarament reflectit al discurs dels ex-membres, encara que una lectura superficial no ens ho permeti veure a causa de la gran insistència a presentar fets concrets com els motius de la desvinculació. La pista correcta ens la proporciona precisament un dels arguments presentat com a justificant de la ruptura $i$ alhora com una prova de la naturalesa maligna de la institució: la pràctica per part d'aquesta del rentat de cervell, la manipulació de les ments i voluntats, la programació, robotització o com es vulgui dir dels membres.

Els ex-membres d'institucions definides socialment com a sectàries expliquen (en el fons en gran part per justificar una tria passada de la qual ara reneguen) la seva entrada i permanència en aquestes remetent-se a la manipulació $i$ engany dels quals han pogut ser objecte precisament a causa d'estar travessant tràgiques circumstàncies o etapes delicades de la vida que el feien més vulnerable i, sobretot, de la seva bona fe. En realitat a un li fa la sensació d'estar escoltant una versió actualitzada del conte de la caseta de xocolata: la bruixa lletja i dolenta que es fa passar per una amable velleta (les sectes) per enganyar els confiats i càndids Hansel i Gretel (els membres de la societat) i un pare molt bo però que no s'assabenta de res i una madrasta que maltracta els fillastres (les dues cares de la societat). La cantarella, si fa no fa, segueix sempre aquest mateix esquema: jo he patit molt. Mireu tot el que em feien. I jo ho suportava tot resignadament perquè tan bo jo, tant de bona fe que anava, sense malícia (tan vulnerable en definitiva), com que tenia una bena als ulls perquè $\mathrm{m}$ 'ho presentaven tot $\tan$ bonic $\mathrm{i}$ em feien creure tot el que volien valent-se de sofisticades tècniques de manipulació de consciències (tan dolents ells, tan mancats d'escrúpols i tan vius), no era conscient de l'engany. Fixeu-vos que fins i tot era feliç perquè creia que estava en el camí correcte i ho suportava tot per tal d'avançar en aquest camí. Ara que he caigut del ruc sóc conscient de tot el que he patit, els anys que he perdut, com he estat d'equivocat, etc.

Ara bé, cauen del ruc realment aquesta gent? Es a dir, passa com ells sovint expliquen: en un moment determinat els cau la bena dels ulls i s'adonen de la veritable naturalesa de la institució, la irracionalitat dels seus postulats i l'engany i explotació de què han estat objecte? Jo més aviat crec que el que fan la major part de vegades és baixar d'un ruc per pujar a un altre i justificar la seva mesura argumentant sobre la incapacitat del ruc abandonat. Però deixem-nos de rucs i d'imatges metaforiques i anem al gra. Per a això els ex-Testimonis de Jehovà resulten especialment il-lustratius, ja que solen ser persones pujades amb una educació catòlica que, en un moment determinat, s'incorporen a una altra institució també cristiana i caracteritzada pel seu fort anticatolicisme per a, finalment, després de trencar amb ella, retornar als seus orígens catòlics.

Un ex-Testimoni explica com la institució expulsà uns membres amb l'acusació d'haver menjat botifarra, considerant la mesura desproporcionada i irracional. Seguidament fa notar que la veritable causa de l'expulsió no era la transgressió del tabú alimentari, sinó que aquests membres anteriorment havien posat en dubte l'autoritat d'alguns germans situats en un esglaó superior i fins i tot alguns postulats tedrics, convertint-se en un "mal exemple" per a la resta de fidels, cosa que li serveix per acusar la institució d'autoritarisme, nepotisme, etc. Aquesta persona explica també que ell ha superat la mala experiència viscuda $i$ ha trobat la felicitat i la pau en el si de l'Església catolica, a la qual ha retornat (i de la qual mai, diu, hauria d'haver sortit). Ben segur que en el moment en què retreia això a l'anterior institució, un cop retornat a l'Església catòlica, no deixava de dejunar els divendres de Quaresma sense considerar aquesta pràctica irracional i acceptava el postulat sobre la infal-libilitat del bisbe de Roma sense consider-lo una mostra d'autoritarisme.

I és que els models religiosos són, probablement, els més excloents que hi ha. Les argumentacions que es produeixen dins un model són vàlides només dins d'aquest, no són 
extrapolables a un altre ${ }^{11}$. Admetre que ho fossin seria tant com afirmar des d'un model determinat que tot es redueix a una qüestió de creences i de llibertat de pensament $\mathrm{i}$ que qualsevol model és eficaç. Això reduiria l'eficàcia dels models. Potser per això, encara que en principi tothom està d'acord amb la llibertat religiosa, sempre s'acaba argumentant (des del propi model) que en alguns casos cal protegir les persones d'algunes creences especialment perilloses $i$ uns cultes particularment perniciosos. Així es justifica el control del creixement de la influència d'altres models. D'aquestes creences, postulats $\mathrm{i}$ idees contra les quals diem que cal lluitar hi ha versions equivalents dins el nostre propi model que, paradoxalment, no qüestionem i no sentim necessitat de protegir-nos-en. I és que, com ja hem dit, els models religiosos són per principi contraris a les extrapolacions. I incompatibles amb qualsevol altre model. Els discursos dels ex-membres sobre el model abandonat i la institució que el sustenta es fa sempre des d'un altre model i, per tant, des d'una posició hostil.

La veritable naturalesa de la institució, les seves característiques i els seus postulats en el fons no són motius de ruptura. Un pot sortir d'una institució al-legant que els seus postulats són irracionals per entrar en una altra que es guia per les mateixes idees i els mateixos valors. Es la percepció (canviant) que l'individu en té el que determina la decisió de desvinculació, igual com anteriorment determinà l'entrada i permanència. I en aquesta percepció les imatges i estereotips socials juguen un paper decisiu i determinaran la naturalesa del discurs.

Arribats a aquest punt ens podem preguntar per què es produeix aquest canvi de percepció envers la institució. En darrer terme caldria considerar la resposta, si no la causa de la ruptura, sí l'explicació. Això ens duria a parlar de mecanismes psicologics complexos, de les pugnes que es produeixen entre dues o més socialitzacions (i models, per tant) diferents i autoexcloents en individus amb les seves particulars trajectòries i experiències vitals en un context, un moment $\mathrm{i}$ unes circumstàncies determinades.

La "segona socialització religiosa", els valors, creences i normes de vida inculcats per la institució "sectària", poden tenir una força especial ja que un els ha assumit voluntàriament, d'una forma conscient. Però la primera compta també amb no pocs avantatges: D'una banda el model religiós inculcat durant aquesta primera socialització forma part d'un model ideologico-cultural més

11 Amb tot, les persones passen d'un model a un altre contínuament amb relativa facilitat. No hem de concloure per això, però, que l'afirmací anterior queda desmentida. Simplement el que passa és que els individus en fan un ús dels models en igual o major mesura que aquests ho fan d'ells. La tria d'un model des d'un altre que el desqualifica és quelcom que sempre s'ha donat. Hi ha però qui, tot i haver-ho experimentat personalment, no s'ho acaba de creure, com aquesta exTestimoni: "...Yo caí en las garras de esos lobos voraces, como otros muchos incautos, por las circunstancias. Habia perdido un hijo de corta edad... Vieron que yo estaba obsesionada con el deseo de poderlo volver a ver en la resurrección, y ellos me halagaron esa idea... Hoy me pregunto cómo es posible que me embaucaran y llegara a aceptar tantas barbaridades como enseñan los Testigos. ¿Y por qué tuvo que ser la cuestión de la resurrección lo que me empuj6 a liarme con esos seỉores y abandonar la iglesia católica?. ¿Acaso no hablamos aprendido desde nin̄os el credo, donde decimos: creo en la resurrección de los muertos?. La triste realidad es que me cazaron y con ellos estuve cuatro años... $*$ Un altre acusa al seu antic grup de ser una institució bumana que, sense estar sancionada divinament, fa de les necessitats espirituals dels homes un negoci."...Todo esto me llevó a estudiar a fondo la historia de los Testigos de Jehová... ¿Cuándo se fundaron los T. de J.?. Sencillamente, a últimos del siglo pasado, por Carlos Taze Rusell, americano. Le sucedió otro americano, el juez Rutherford. Actualmente los dirige Natham H. Knorr... ¿ Cómo puede ser verdad una religión fundada por hombres vulgares cualesquiera?. ¿Qué fuerza tiene una religión apartada de aquellos apóstoles que escucharon del mismo Cristo cómo tenía que constituirse y gobernarse su iglesia?...*. Aquesta crítica la fa des del model religiós catolic al qual ha retornat. Pet aix no podem deixar de notar que la seva argumentació és prou curiosa. Segurament no ignora que d'aquell a qui considera l'Església catòlica el seu fundador es va dir amb menyspreu: com ha de ser aquest el Messies, no és el fill del fuster i ha aascut en un poble de mala mort?. No ignorarà tampoc que el fill de Déu va triar com a primer cap de la seva església Pere, un home vulgar, un pescador. La mateixa església catolica ho ressalta com una mostra de la grandesa de la institució basada no en el poder, les ostentacions materials o facultats intel.lectuals, sinó en allo que d'espiritual i bondadós hi ha en la naturalesa humana. I si el Senyor Knorr no ha escoltat mai de boca de Jesucrist com s'ha d'organitzar i governar la seva església, el mateix es podria dir del Sant Pare. Acceptar com a successor legítim dels apdstols un o un altre no és més que una qüestio de fe. 
ampli que correspon al context sòcio-cultural viscut per la persona a més de ser el socialment normatiu. D'altra banda, i en part pel que acabem d'assenyalar, aquest procés de socialització no acaba mai, acompanya la persona fins al dia de la seva mort vulgui o no vulgui, ja que no deixa mai de ser membre d'una societat determinada i d'estar-hi influïda per molt que se situï en certa forma en la marginalitat (en realitat és la societat que li atorga aquesta posició perquè per adoptar un model religiós diferent és sospitosa, si més no simbolicament, de posar en dubte tot el model). Fins i tot encara que visqués aillada (una acusació que es fa a les sectes és la de privar els seus membres de tot contacte amb el món exterior) tot allo inculcat a la persona des del bressol i durant els anys d'infantesa i primera joventut, quan no tenia prou elements per contrastar-los i jutjar-los per manca d'informació i experiència directa, per força queda molt interioritzat i pot reactivar-se facilment. Els membres d'aquestes institucions no poden, encara que vulguin, ni esborrar el seu passat ni evitar el seu present. La societat aboca contínuament sobre els seus membres (i ells ho són) tota mena de missatges, imatges... Aixd ens ajuda a comprendre per què es produeixen moltes ruptures i també perquè els seus discursos posteriors són d'una determinada manera i de cap altra, com veurem a continuació.

\section{El discurs de l'ex-sectari sobre la institució abandonada. Contingut, naturalesa i forma}

En tots aquests discursos, construïts a posteriori a partir dels elements que l'experiència personal ofereix però adaptant-se a un model socialment preexistent que els condiciona, hi podem distingir dos nivells:

Un de "visceral", que ens parla de patiment, sentiments ferits, amistat traïda, temps perdut, etc. Resumint: experiències traumàtiques o si més no negatives. Aquest component del discurs sorgeix de l'individu com a tal $\mathrm{i}$ va dirigit a la resta de membres de la societat en tant que individus ells també; per això parla de sentiments i apel-la als sentiments. Amb ell l'individu pretén fer-nos partíceps dels seus sentiments, fer entendre les seves actituds i decisions... i despertar la simpatia i el suport del receptor del discurs.

En el discurs d'aquestes persones decebudes espiritualment (i humanament) no podem pas deixar de constatar, en tots sense excepció, una mateixa cantarella...; m'estic referint a una mena d'exhibicionisme sentimental que en alguns casos deriva cap a unes disseccions del patiment gairebé malatisses i morboses en excés. En part el discurs està destinat (i això el fa més efectiu perquè podem dir que és el que permet lligar els diferents arguments del discurs i actua com a fil conductor) a mostrar l'experiència del discursant en el si de la institució abandonada que se'ns presenta com a negativa. Fent-nos partíceps de la seva experiència personal, aquestes persones pretenen reclamar la nostra atenció, aconseguir la nostra comprensió i simpatia i, en determinats casos, despertar reaccions, opinions i actituds contràries a la institució. "Mireu com he patit, com m'han deixat, com m'han explotat, quants anys he perdut darrera una mentida, etc.", ens diuen. Aquest component del discurs és com ara la banda sonora d'una pel-lícula. Sempre hi és, s'agraeix quan es limita a crear l'ambient adient, però quan un no pot deixar de notar-la perquè reclama estridentment tot el protagonisme aquesta cantarella pot arribar a esperpentitzar el discurs totalment. A més, aquest component sentimental no és suficient per mantenir en peu el discurs total i perquè aquest transcendeixi socialment, que és el que en alguns casos es pretén.

L'altre nivell del discurs, que podríem anomenar racional, l'individu ens el presenta com una anàlisi de la seva experiència com a membre de la institució i un judici i valoració objectiva basats en aquesta experiència. Està conformat sobre la base d'una sèrie d'acusacions contra la institució recolzades en el coneixement directe i l'experiència personal. Aquest component del discurs sorgeix de l'individu, en tant que membre de la societat, cap a la resta d'individus, en tant que membres també de la societat. L'individu i el seu discurs juguen amb la complicitat que aquesta pertinença comuna proporciona però, també s'hi poden veure condicionats segons els casos, el 
context $\mathrm{i}$ les circumstàncies.

Fets i circumstàncies concretes, així com constatacions basades en una vivència personal, són presentades com a proves de la mialignitat intrínseca de la institució abandonada. En realitat l'aparició d'uns determinats fets i no uns altres en el discurs s'ha de relacionar amb una tria condicionada pel fet que es pretén il-lustrar uns arguments concrets que als discursants ja els vénen donats. Per tal d'il-lustrar aquests arguments, els fets són interpretats d'entre totes les opcions possibles d'una forma molt concreta. En aquest procés de tria $\mathrm{i}$ interpretació entren en joc molts de factors que guien i al temps condicionen l'individu. Bàsicament el fet de pertànyer a una societat que té una imatge social molt concreta de la institució de la qual parla i, sobretot, el fet de produirse un cop fora ${ }^{12}$.

El discurs antisectari dels ex-membres d'institucions religioses no legitimades socialment s'estructura sobre la base d'unes acusacions que pretenen farcir unes afirmacions generals que ens parlen de les repercussions negatives que sobre els seus membres comporta la pertinença a la institució acusada de sectarisme. El missatge és prou clar: aquestes institucions són un perill social, cal protegir-nos-en i desemmascarar-les per tal que ningú caigui a les seves urpes. La intenció que guia el discurs és més que evident: desqualificar la institució.

Les acusacions concretes són moltes i una enumeració exhaustiva resultaria excessivament llarga. El que sí farem és apuntar quines són les afirmacions acusatòries de caire més general. La més important, ja que és la que constitueix l'eix sobre el qual es fonamenta tota acusació de sectarisme, és afirmar que la institució destrueix la naturalesa psíquica de l'home: la seva voluntat i llibertat de pensament i acció. L'etiquetatge de sectarisme i l'acusació de programació, manipulació de consciències i voluntats, etc, van indissolublement lligades. Encara hi ha, pero, una altra afirmació general que afecta només determinades institucions catalogades com a sectàries: són acusades obsessivament de destruir la naturalesa espiritual de l'home i la seva $\mathrm{fe}^{13}$.

12 El procés, en aquest aspecte, no és pas diferent al que acompanya a l'entrada a aquestes institucions. L'individu, en un primer moment, s'hi incorpora se sent ben acollit i esperançat pel que aquestes propugnen. Un cop ja dins anirà prenent forma el discurs racionalitzador de la seva entrada. Un procés aquest igualment guiat $i$ condicionat. En aquest cas pels postulats de la institució de què s'ha passat a formar part i pel fet de fer-se des de dins del model per ella propegnat. Tant la decisió d'adscripció com la de la ruptura reben posteriorment una cobertura de racionalitat que potser comença abans de la pròpia decisió però continua bastint-se més enllà en un procés continu i mai tancat...però que també pot girar-se radicalment.

13 Aquesta acusació es produeix bàsicament en el cas dels ex-Testimonis de Jebovà. Un ens explica: "...De religión mal; estoy en un estado que no sé qué hacer, aunque yo creo en Dios. Pero la Biblia se presta a tantas interpretaciones que no tengo ánimos suficientes por ahora para seguir buscando la verdad...j Me han destrozado espiritualmente los testigos!...". Les paraules d'aquest altre encara són més significatives: "...Los falsos Testigos de Jehová han incidido terriblemeate en mi espiritualidad y han conseguido que pierda una gran parte de mi fe. Estoy atravesando una gravísima crisis espiritual cuando esto ha sido siempre mi fuerte; espero que Dios tenga compasión de mí y me ayude en gran manera porque de lo contrario estoy definitivamente perdido...".

No són mai objecte d'aquesta acusació aquelles institucions catalogades com a sectes no pertanyents a la famflia cristiana. Possiblement perquè, si bé es reconeix fins a cert punt que existeixen alternatives espirituals acceptables fora del catolicisme però dins del cristianisme, de cap manera poden existir fora de la familia cristiana (o les considerades grans religions revelades). No es dirà mai per exemple: els Hare Krisna destrueixen la fe de l'individu. No, això seria admetre que son un grup que ofereix una alternativa espiritual $i$ que la gent s'apropa a ells per raons de creences $i$ aquesta inatge no interessa. Interessa demostrar que s'apropen a ells persones amb característiques o circumstancies "anormals", interessa representar-los com uns torrats amb el cap pelat, vestits de forma extravagant i repetint convulsivament paraules indesxifrables, no com a homes de fe. Com que la imatge que ens arriba d'ells resulta esperpèntica (com qualsevol estereotip) ens provoquen llastima o somriures des d'una posició de superioritat, sense adonar-nos que els nostres capellans o monjos són gairebé igual de xocants mirat objectivament. També van vestits amb túniques fins als peus, alguns viuen en commitats tancades sense relació amb el món exterior, sense parlar amb cap altre ésser humà, i fins no fa gaire repetien mecànicament paraules indesxifrables per als no iniciats. Curiosament aquesta acusació no recau sobre una institució que, tot i ser casblica, és catalogada de sectaria en ocasions. M'estic referint a I'Opus Dei. I molt menys encara sobre institucions catōiques tradicionals, totalment legitimades socialment. 
Totes dues acusacions provoquen reaccions i actituds. La nostra és una societat que, declarant-se aconfessional, formula uns "valors civils" dels quals s'erigeix en defensora. Aquests principis es poden resumir en una idea: la salvaguarda de la libertat i dignitat humanes. Quan l'exsectari, en el seu discurs, acusa la institució abandonada de violar aquests principis (denunciant pràctiques humiliants, explotació, manipulació de la voluntat, etc.) actua com a membre de la societat que té interioritzat aquests valors. L'ex-sectari connecta amb la resta de membres de la societat per parlar d'un tema d'interès (els principis sobre els quals, en la representació ideal que ens fem de la realitat, es basa el nostre món) i en defensa d'uns valors compartits per la comuna pertinença. El seu discurs despertarà, si més no, interès. Molt sovint provocarà també actituds i opinions davant un fenomen: el d'aix que anomenem sectarisme. Quant a l'altre gran argument, si es donen també acusacions en el terreny de l'espiritualitat és perquè aquestes no cauen pas en un sac buit; troben una acollida $\mathrm{i}$ generen reaccions. En la nostra societat, per molt civil i aconfessional que es declari, el fet religiós té un gran pes específ. La defensa de la llibertat religiosa és també un valor civil, la fe un sentiment que s'ha de respectar perquè així està estipulat legalment i socialment. Sap el que es fa una persona que acusa una institució d'explotar la gent aprofitant-se de les seves inquietuds espirituals i de destruir o danyar greument la seva fe com a conseqüència de l'experiència vital a ella lligada.

\section{El preu de la reinsercio: representar el paper de víctima i reproduir el discurs antisectari}

L'anàlisi del discurs dels ex-membres d'aquelles institucions religioses catalogades socialment com a sectes és prou interessant $\mathrm{i}$ especialment fructífer, si va acompanyada d'una comparació amb els discursos d'ex-membres d'institucions religioses legitimades socialment. La comparació de fenòmens equiparables i confrontables ens permeten adonar-nos d'aspectes que, d'altra manera, podrien passar desapercebuts, així com també ens poden portar a relativitzar i matisar d'altres que no ens hauríem molestat a analitzar críticament, donant per certes afirmacions pre-existents i construint postulats a partir d'aquestes.

Fins aquí hem analitzat els discursos d'ex-membres d'institucions definides socialment com a sectes. S'hi insisteix en la naturalesa intrínsecament maligna de la institució abandonada. La imatge que se'ns vol transmetre és que els membres (ells ho van ser un dia) són víctimes d'una estructura institucional de caràcter gairebé diabòlic. L'ex-sectari, al seu discurs, diu que se sent amb el deure d'explicar a tots el que a ell li ha passat perquè ningú més hagi de passar per aquesta experiència i llença contra la institució abandonada multitud d'acusacions, alguns cops presentantles com a raons de la ruptura.

Però, què passa amb els ex-membres d'institucions catòliques, amb el contingut $i$ el missatge del seu discurs?. Sovint el relat de la seva experiència en el si de la institució abandonada ens permetria bastir una acusació de sectarisme modèlica. Però aquestes no apareixen mai; l'ex-membre pot llençar acusacions contra la institució, però aquestes queden neutralitzades pel fet d'estar inscrites en un discurs amb un missatge que, com a molt, pot ser reformador, en cap cas desqualificador ${ }^{14}$. Les crítiques, poques $\mathrm{i}$ molt matisades, i les acusacions, escasses i puntuals,

14 ....La vida aquesta era...tan programada que no tenies temps de desprogramar-te...No tenies temps ni de pensar res, perquè ja t'ho portaven tot programat...(aquesta sensacio) la vaig sentir quan vaig sortir a donar classe...vaig teair la sensació de què estava explotat...Si he tingut sentiments o el que sigui, no els he pogut pas dir, potser a mitges, o ni a mitges... No podies confiar en ningú perquè, i si aquell ho deia al Superior?...*. Tots els components necessaris per elaborar una acusació de sectarisme (programació, explotací6, tècniques psicològiques de control...) amb molt menys s'han fet. Però no en aquest cas perquè qui parla és un ex-germà de la Salle. En el seu discurs a tot això no se li atorga gran rellevància, perquè no és un missatge desqualificador el que es vol donar. De fet, més endavant aquesta mateixa persona diu: "...Jo, en 
s'inscriuen en un discurs reformador. Els ex-membres d'institucions catoliques tradicionals no qüestionen mai la conveniència o no de l'existència de la institució. Si són preguntats expliquen la seva ruptura sobre la base d'una manca de vocació, i si existeix alguna crítica a la institució es basa en la mala gestió dels individus, mai en la seva naturalesa. El missatge que ens arriba és que si ells han viscut una mala experiència en el seu si (que explica $i$ justifica la ruptura), no és per causa de la naturalesa de la institució sinó de les persones que en aquell moment i lloc concret la dirigien i gestionaven (interpretant erròniament el seu esperit) o per una decisió personal equivocada (com el fet d'haver-hi entrat sense una vocació suficientment definida, per exemple). Però, a poc que hi aprofundim -i malgrat les diferents intencions que guien els discursos, que no poden pas deixar de condicionar-ne el contingut (mentre uns insisteixen en uns temes $\mathrm{i}$ ressalten uns fets viscuts $\mathrm{i}$ uns sentiments experimentats-durant el temps passat en el si de la institucio, els altres, tot i haver observat fets de la mateixa naturalesa i experimentat idèntiques circumstàncies i sentiments, en parlen molt pel damunt i sense responsabilitzar-ne totalment la institució) ens adonem que en rehació amb les seves experiències vitals en el si de les respectives institucions les històries d'aquestes persones tenen molt més en comú que no pas discrepàncies ${ }^{15}$.

general, a aquesta gent no els hi guardo ressentiment. No, de veritat. Potser algú va ser molt bèstia...però com a instimció, més aviat sento una certa simpatia...fins i tot crec que sóc normal, ni especialment atemorit, ni preocupat, ni res....

Especial és el cas d'una institució catolica, si bé no tradicional: l'Opus Dei. Alguns cops el discurs s'adspta al model de les institucions catoliques tradicionals (missatge reformador, la institució no queda desqualificada) però tanbé es pot adaptar al model sectari. Fins i tot el discurs d'una mateixa persona pot oscil.lar d'un model a un altre. Veien-ho: "...Tuvimos un total aislamiento con el exterior durante esos seis meses en el centro de estudios. Y esto, curiosameate, es una característica de las sectas...No se nos permitía tampoco bacer o recibir llamadas telefónicas. Las cartas que escribćmos teniamos que entregarlas abiertas para que las censurase la directora, $\mathbf{y}$ aquellas que recibiamos nos llegaban igualnente abiertas y leidas por la directora. Esto se sigue baciendo boy día en todas las casas del Opus Dei..."ens explica ma exnumerària de I'Opus Dei. L'acusació clara de sectarisme no li fa, però, desqualificar la institució: “...puedo garantizar que carezco de amargura. A muchos nos queda, eso sí, el sentimiento dolorido....de ver que algo que podría ser grande y maravilloso -la Obra- quede reducido a cosas que tanto desdicen de su propia autenticidad... ${ }^{*}$. Una altra diu: *...A esta altura de mi vida puedo ver claramente que uno de los medios a través del cual el Opus Dei encamina a sus miembros al fanutismo es precisamente el abolir de sus mentes, bajo pretexto de formación, todo aquello que, de cerca o de lejos, se asemęe a la más velada critica a la Institución....El lavado de cerebro consiste precisamente en bacerles ver a los mienbros, particularmente en la primera hora, que la Obra es perfecta porque es de Dios...la confidencia, en el Opus Dei, es la forma de control más absoluto de la libertad humana de sus miembros y una forma también muy clara de lavado de cerebro que, aún sin llamarlo tal y bajo capa de "buen espíritu" o de "formación", se lleva a cabo en todos los miembros del Opus Dei...*. Malgrat aquestes paraules tan dures, defensa la institució, el seu esperit, que considera trait: "...Si algo entra dentro de mis deseos es precisamente que la Obra de Dios, recuperando su genuino espíritu, sea el instrumento de apostolade para el que Dios la inspiro...La Obra puede tener un origen y unos fines todo lo sobrenaturales que se quiera, puede tener maravillosas posibilidades. Lo que hace precisamente más necesario reaccionar ante aquello que desmerezca. No es bgico ocuparse de algo en lo que no se cree o no se tiene interés. La Obra, en principio, creo que lo tiene...

${ }^{15} \mathrm{Com}$ ja hem dit abans, és, perfectament factible bastir una acusació de sectarisme a partir de l'experiència viscuda en el si d'una institució catolica tradicional. En els discursos d'ex-membres d'aquestes institucions trobem prou elenents per fer-ho: acusacions de programaci6, explotacio, manca d'intimitat i control humiliant del membres per part dels superiors, aillament del món exterior...Veiem-ho: “...vaig tenir la sensació que estava explotat...vaig pensar: per ser mestre no et cal tot aixd...Representa que des de l'any 80 treballo, és a dir, tine cartilla de la Seguretat Social, la veritat sigui dita. Aquells anys no els podró recuperar mai, ningú em garantitzara que jo els vaig treballar. Això que els vaig treballar molt mús que ara...No tenfem Seguretat Social..." ens explica un ex-germà de la Salle, que en un altre moment també parla de programaci6. Rememorant-ho arriba a dir: "...quan m'ho repenso dius: carai, noi!, com ho vas aguantar aixठ; com ho vares aguantar allठ; què vares fer?..." i aquestes constatacions no el duen a desqualificar la institució ni a culpar-la de tots ela seus mals. L'únic responsable és ell mateix, que va fer una tria equivocada: "...tine potser la convicció que allo, ser frare, no bo vaig voler ser mai. Jo el que volia ser era mestre. I potser va ser una torpesa meva o una de les possibilitats d'entrar en aquest món i trobar-me que després va ser una sortida cap aquest món... . Un ex-carmelita explica la ruptura de forma molt similar: "...la meva vocació no tenia massa sentit, feia les coses per inèrcia no per convenciment...no m'hi trobava útil dintre l'orde dels carmelites...vaig arribar a pensar que el que feien ells com a frares, ho podia fer jo com una persona normul...". Pero de seguida afegeix, no sigui que les seves paraules siguin mal interpretades: "...crec que els Carmelites tenen $\mathbf{k}$ seva funcio dintre I'Església...". Però aquesta ex-multi-sectària, experta a descobrir els símptomes de la síndrome del secturisme 
Què ens mostra una anàlisi contextualitzada? Que en realitat en tots dos casos l'individu negocia amb la societat el seu nou estat i vol justificar una decisió. En un cas es vol justificar una pertinença passada, en l'altre, un abándonament. Totes dues decisions són susceptibles de ser interpretades com a traïcions a la societat. L'ex d'institucions catoliques no desqualifica la institució perquè no vol que la ruptura pugui ser interpretada com una traïció al model social general (en el qual la institució abandonada no sols té cabuda, hi té un paper i un pes). La intenció reformadora que guia acusacions puntuals (que tenen una missió molt concreta: justificar o fer entendre el seu abandonament) és una constatació que la ruptura no comportava el qüestionament d'una institució socialment sancionada. L'ex-sectari també vol deixar clara la seva relació amb la societat. Simbòlicament la va trair amb la pertinença a una institució no legitimada socialment. Amb el seu discurs i la seva actitud anti-sectària aquests individus vénen a fer una declaració pública de fidelitat a la societat. Adoptant el paper de víctimes i acusant de tots els mals del món la institució abandonada assumeixen un paper $\mathrm{i}$ una actitud amb què proven la seva intenció reconciliatơria $\mathrm{i}$ s'excusen d'una decisió passada i de la pertinença "desviada" que aquesta comportà.

La societat els ho posa molt facil. De fet és la que els aboca a representar aquest paper. Hi ha un discurs social general tendent a victimitzar les persones alhora que criminalitza les institucions i remet a una explicació que disculpa en part els individus sobre la base d'unes circumstàcies desfavorables que els condicionen negativament ${ }^{16}$. Les persones queden així desresponsabilitzades de les seves accions i decisions, de les seves adhesions i "infidelitats*. El sectari en concret és considerat (o almenys representat) com una víctima innocent que cal alliberar d'allo i aquells que l'oprimeixen.

Però compte!, tot té un preu en aquesta vida: si la societat ofereix a aquests fills pròdigs (una vegada han adquirit l'estatus d'ex-sectari) l'oportunitat de presentar-se com una víctima, també els "obligarà" a representar aquest paper al servei de la comunitat fins a la sacietat. I aquesta és la creu de la moneda.

El sectari que ha "retornat a la societat" $i$ ha estat rebut i "perdonat" ha de mostrar el seu agraiment tota la vida actuant conforme al que d'ell s'espera: ha d'estar disposat a mostrar les seves nafres públicament, les ferides mai tancades totalment causades pel seu pas per la institució sectària. El retorn implica automàticament carregar amb una etiqueta (la d'ex-sectari) i haver de representar un paper amb un guió ja escrit: bàsicament presentar-se traumatitzat per l'experiència sectària. El problema és que hi ha actors que viuen massa el seu personatge... Jo diria que és per aix $\partial$ que molts ex-sectaris acaben passant per cal psicoleg, i no tant per les seqũeles que els queden del seu pas per la institució "sectària". L'ex-sectari és menys un producte de les sectes que de

en les persones després del seu pas per Pro Juventut i el psicoleg, ho té molt clar i no es mossega la llengua: *...mi hermano...va a los Salesianos, es un colegio católico normal... van de convivencias... ¿ Cómo volvió? Es un crío normal pero muy sensible. El crío es bruto, es animal, lo que quieras, pero lo tienen tres días alli encerrado y yo lo vi cuando wolvio a casa...con los ojos así brillantes.... Y mi madre...superorgullosa de w hijo porque venía iluminado por Dios. Ni iluminado por Dios ni hostias; venía colocado de rollos que le babían metido....

${ }^{16}$ Aixð es manifesta potser més clarament en altres fenòmens com ara l'alcoholisme $\mathrm{i}$ altres drogodependències o certes activitats catalogades com a delictives. Allo que abans era considerat com a vicis (dels quals un és l'únic responable $\mathrm{i}$ culpable) és presentat ara com una patologia (de la qual un és víctima). Fins i tot hi ha una tendència (si bé convie amb d'altres contràries) a considerar els trangressors de les normes amb cobertura legal com a victimes, explicant les seves conductes "desviades" partint de circumstàncies socials i familiars negatives que els determinen.

El discurs teòric sobre els fenòmens catalogats socialment com a problemàtics ha variat al temps que canviava la tactica per intentar tenir-los controlats. Hi ba coses, però que romanen invariables. Tant abans com ara les actuacions (tant preventives com a posteriori) pretenen incidir en la problemàtica a través de les actuacions sobre persones, mai es plantegen actuacions sobre les circumstancies estructurals que estan implicades en el fenomen. I, encara que avui existeixi una tendència a presentar les persones com a víctimes, ningú s'escapa al càstig social: aquest consisteix a carregar al denunt una etiqueta que, per molt desculpabilitzadora que sigui, no deixa de ser estigmatitzant. I quan a un I'etiqueten, ja $\infty 0$ pot escapar: ha de suportar tot un procés terapèutic que comporta alhora un "càstig" i un control. 
l'autoreencarnació induïda des de l'exterior d'una abstracció social: la del sectarisme com a fenomen de perillositat social.

La representació del paper de víctima comporta l'acceptació d'un càstig aparentment tou sentit com una mena de ritual purificador i reconciliatori necessari perquè simbòlicament l'individu va trair la societat quan es va incorporar al grup sectari (va transgredir unes normes no escrites ni explicitades). Com que l'individu no és considerat totalment responsable de la transgressió, el càstig es tradueix en una mena de serveis comunitaris: servir de símbol dissuasori, de mostra viva de les repercussions negatives del sectarisme (considerat aquest com a conducta desviada) sobre la persona, sobre el transgressor.

Hem dit que és aquest un càstig tou només en aparença. També hem insinuat que el paper de víctima que la societat ofereix als ex-sectaris és per a ells alhora un regal de la providència i el preu que han de pagar per ser acceptats de nou. La imatge social de les sectes ens les presenta com a institucions d'una naturalesa instrínsecament maligna que deixen a qui passa per elles trastornat i trastocat. L'ex-sectari mai arriba a recuperar-se totalment de la seva experiència, aquest és el missatge. I el que fan els ex-sectaris és representar el paper adaptant-se a l'estereotip social existent. Estereotip que els seus "alliberadors" (amb intervencions directes o no; alliberadors abstractes i passius -la societat amb els seus valors, missatges, estereotips etc. -0 amb noms o sigles concretes) s'han preocupat que interioritzés bé.

Ex-sectaris "rescatats" per familiars o amics que els porten a associacions com ara Pro Joventut o els sotmeten a desprogramacions o tractaments psicologics acaben sentint-se víctimes de la "secta". Se'ls fa sentir desgraciats amb efectes retroactius, convertint una experiència passada viscuda positivament en un record que repercuteix en el present traumàticament $\mathrm{i}$ condiciona negativament el futur. A això em referia quan apuntava el problema que representa que alguns es creguin massa el paper que representen. Els ex-sectaris es veuen abocats a exposar públicament les seves ferides per tal d'aportar unes proves contra els agressors (la institució sectària)... En realitat molts cops les ferides són autoinfringides amb posterioritat per inducció, hagi existit o no l'agressió (o hagi estat o no aquesta sentida com a tal en el moment de rebre-la). També se'ls indueix a no deixar tancar mai unes ferides descobertes un cop fora de la institució; una cicatriu no colpeix tant com una ferida oberta, sagnant i purulenta. Es per això que molts ex-sectaris, insconscientment, es prohibeixen a ells mateixos superar el trauma.

Associacions com Pro Joventut, familiars i amics, psicollegs, legisladors, etc., no hi ha dubte que actuen amb tota la bona fe del món. Creuen en la perillositat de les institucions contra les quals lluiten $i$ en les repercussions negatives que l'adscripció a aquestes té sobre els individus $\mathrm{i}$ actuen en conseqüència. Però també és cert que a causa del seu interès per contribuir a eliminar o controlar un fenomen definit com a problema recreen artificialment el problema en la ment de les persones a les quals es considera afectades (manipulant els seus records i sentiments ${ }^{17}$ ) per poder actuar sobre ell. Les víctimes d'aquest zel redemptor són els sectaris. Són "rescatats" o " alliberats" sense haver-ho demanat, se'ls aplica una teràpia per tal de fer desaparèixer una simptomatologia que la societat considera indicadora d'una greu malaltia sense ell sentir-se malalt $i$, finalment, acaba per acceptar la seva condició de malalt i el tractament de xoc. Sense ser aquesta la seva intenció,

17 El procés pel qual es convenç una persona que alla on està és una secta, que és perillós per a ell romandre-bì $\mathrm{i}$ que ha de sortir-ne (que té un problema en definitiva) consisteix, no ens enganyem, en una reprogramació utilitzant la terminologia dels "rescatadors". Així bo reconeix clarament (potser sense ser-ne gaire conscient) un ex-gnðstic que ba experimentat aquest procés parlant de la possibilitat de "recuperar" la seva xicota, gnòstica encara: "... Yo, viendo que no podía luchar con ella porque eso es cuestión de desplazar totalmente a una persona y hacerle un buen lavado de coco, las cosas claras, y bueno...tampoco podía estar detras de esta chica las 24 horas, vigilándola...al final lo dejamos estar, ella siguió en su mundo y yo segú el mío... Yo no soy nadie para decirle baz esto o baz lo otro, cada uno es libre de bacer lo que quiera...". Un rescatat sense vocació de rescatador. No deixa de ser curiós com no fa amb una persona el que $\mathrm{L}$ han fet a ell per respecte a la seva llibertat, però racionalitza el que amb ell han fet també basant-se en la defensa de la seva llibertat. 
un salvador. Aquests ex-sectaris tenen una gran habilitat a presentar la seva experiència personal com una història d'interès social. El seu missatge és senzill i molt enginyós: això que em va passar a mi pot passar a qualsevol membre de la societat, el meu drama pot ser demà el teu. Cal lluitar contra el fenomen de les sectes i la meva missió és fer-vos adonar de la necessitat de reaccionar sense indecisions. Potser no és aquesta la missió que la societat havia previst per a ells, però ja li està bé també.

En què ens basem per interpretar aquesta actitud com una rebequeria inconscient i no un agraïment extrem? En una constatacio: Aquest especimen (l'ex-sectari amb vocació de Casandra i croat) no es dóna mai entre aquells "culpables d'una major traīció" i pels quals la societat s'ha pres més molèsties (ha dirigit el seu rescat i "reinsercio") i que, teoricament, haurien de fer més esforços per fer-se perdonar. No hi ha Casandres vocacionals a temps total (molt menys encara croats) entre els ex-sectaris "rescatats" (gndstics, hares, etc.) als quals els seus familiars o amics hagin portat a Pro Joventut o al psicoleg. Són els "autoalliberats" els que se senten cridats a aquesta missió, ex-Testimonis especialment, però també alguns ex-Opus. L'activisme antisectari altament compromès i viscut com una crida i lluita es dóna entre els "autorecuperats". Es entre aquests que sorgeixen de tant en tant croats vocacionals que practiquen una militància activa. Els rescatats es limiten a respondre mecànicament enfront determinats estímuls; la seva militància anti-sectària es limita a contestar el que està previst quan són preguntats i sobretot a la representació del seu paper de víctima. Aquesta és la funció i el paper que la societat ha previst per a ells i són ells precisament (que s'hi senten més obligats) els que no es poden permetre la "rebequeria" d'assumir un altre paper més prestigiós, ja que podria ser interpretat com una insolència. Cal considerar també que el procés pel qual han arribat a sortir de la institució pot fer que hagin interioritzat més el paper de víctima.

Es curiós que aquells que teoricament són menys deutors de la societat, que no se senten "alliberats" per aquesta sinó per un procés de reflexió personal i lliure sense cap ajut especial, són els més compromesos amb la causa antisectària. També és normal, però. El seu "retorn", la "reconciliació", ha estat fruit d'un procés menys directament manipulat, més espontani i madurat i per aixठ tot se sent i s'expressa de forma més radical i visceral: el sentiment d'haver "trait" la societat el temps que es va pertànyer a la secta, la convicció de la necessitat de recongraciar-se amb ella mitjançant una actitud militant anti-sectària i el rebuig i desqualificació de la institució abandonada. Hi ha molts ex-Opus i ex-Testimonis que han publicat llibres explicant la seva experiència sectària per advertir la resta de membres de la societat contra la institució abandonada. L'únic llibre que explica una experiència personal en el si d'una "secta destructiva" ha estat escrit per un fals ex-membre, un periodista.

\section{El discurs de l'ex-sectari sobre la institució abandonada està condicionat pel fet de no estar aquesta legitimada socialment}

Arribats a aquest punt cal preguntar-se per què havent viscut els mateixos fets i experimentat les mateixes circunstàncies, observant en les institucions actituds i pràctiques totalment equiparables, no tots els ex-membres d'institucions religioses elaboren discursos de la mateixa naturalesa... I sobretot, per què aixd no depèn de característiques intrínseques als mateixos individus sinó de quina sigui la institució sobre la qual el seu discurs versa. Experiències personals gairebé idèntiques ni es racionalitzen ni s'interpreten, ni se senten ni es jutgen per igual ni farceixen discursos de la mateixa naturalesa... tot això depenent de quina sigui la institucio de què es parla. Constatat aixd, un no pot acceptar les explicacions sobre la base de la malignitat intrínseca d'unes institucions i la bondat de les altres que ens són presentades als discursos.

Què és, doncs, el que porta les persones a sentir i interpretar una experiència similar de formes tan diferents?; quins condicionaments, sobretot, els porten a elaborar discursos tan 
radicalment oposats? Inconscientment un és molt conscient del que pot dir i el que no pot dir, el que convé o no dir, el que serà ben o mal acollit si un ho diu; un sap quines actituds i postures li crearan problemes i quines li poden resultar beneficioses o estalviar-li problemes. Un ex-membre d'una institucio catòlica pot fer acusacions puntuals, però el que no farà mai és qũestionar la institucio $\sigma^{20}$. Per què buscar-se problemes innecesaris i escalfar-se el cap rememorant un temps ja passat? Cal ser bastant tanoca i masoquista: no serà escoltat, si es escoltat no serà comprès $i$, a més, serà vist amb mals ulls. Però quan un ha pertangut als Hare Krisna o a l'església Moon, posem per cas, el que s'espera d'ell és una furibunda acusació de sectarisme. En aquest cas pot ser vist amb mals ulls si aquesta no s'arriba a produir. I això no vol dir que es pensi una cosa i se'n digui una altra. Els discursos són sincers, responen al que els individus senten... però és que la forma en què aquests interpreten i senten la seva experiència també està condicionada socialment.

El discurs dels ex-sectaris no es pot analitzar sense tenir en compte tot aixo. Les societats sempre han definit què és el que consideren bo i dolent; de fet, establir el que es considera negatiu o posititu, el que és o no nociu i perjudicial per als seus membres, legal o il-legal, el que té o no cabuda en el seu si i quines actituds, accions, pensaments, etc, són propis d'un bon membre de la societat i quins no, és quelcom que totes fan. D'aquest mecanisme depèn en part l'existència de la mateixa societat, i és una característica que la defineix com a tal... I tant se val si tot això s'estableix a partir de criteris arbitraris... Es normal i lògic que la societat també decideixi en què consisteix l'arbitrarietat dels criteris i com i sobre què cal o no cal aplicar-los, fins a quin punt, quan cal suavitzar-los, etc. Això és evident. Es normal que tota societat trii qui pot o qui no pot rentar el cervell als seus membres, és a dir, fins on es pot considerar que hi ha una socialització i un procés d'aprenentatge normal i quan s'ha de considerar que estem davant una programació; que defineixi quines institucions tenen cabuda en el seu sistema i quines no. Això és el que està passant en la nostra societat amb el tema de les sectes d'uns anys ençà, no ens enganyem. Per tot aixo, si un vol fer una anàlisi seriosa del fenomen del sectarisme, no té sentit limitar-se a ser una peça més de tot aquest engranatge i procedir a mesurar la presència qualitativa i quantitativa de pràctiques humiliants, explotació, programació, etc., en el si de cadascuna de les institucions existents per tal d'arribar a una posterior classificació d'acord amb el grau de malignitat i perillositat social d'aquestes.

No és la veritable naturalesa i caràcter de la institució el que en determina la imatge social i el que genera actituds i reaccions en darrera instància. Els diferents èmfasis en els discursos, el fet de justificar algunes pràctiques, actituds i tractes segons provinguin d'unes institucions o unes altres és quelcom que està predeterminat socialment... Fins $\mathrm{i}$ tot molt abans que aixd que anomenem sectes arribessin a Europa estava ja escrit que serien catalogades com un perill social. Potser mai haviem viscut la presència d'aquest fenomen, però sí de fenòmens equiparables i la resposta ja havia estat elaborada molts cops. Ara tan sols cal adaptar-se a un model ja existent.

Si la irrumpció en la nostra societat de multitud d'institucions "estranyes" que ofereixen alternatives espirituals provoca fortes reaccions no es deu tan sols a un zel defensor de la tradició cultural i la identitat. No es tracta d'una resposta en forma d'anticossos socials provocada per la

\footnotetext{
${ }^{20}$ La seva posició és més ambigua i delicada que la d'un ex-sectari. L'ex-sectari, rebutjant la institució rebutja també tot un model; ell, sortint de la institució, encara $t s$ dins el model (segueix sent catòlic o si més no membre d'una caltura catolica). Es curiós que fins i tot a nivell d'etiqueta hi hauria problemes per declarar-se un renegat del catolicisme. Un es pot definir com a no practicant o no creient però l'etiqueta d'ex-catòlic sembla no existir. I ́́s que un pot ser un membre més o menys apàtic o participatiu, fins i tot situar-se al marge de l'Església catolica perd̀ canviar-la per una altra institució no. Crítiques dels de dins es poden tolerar, però no dels que han sortit fora. Es per aixdे que si una persona de fornació catolica, rememorant el seu passat, es mostrés dolgut $i$ traumatitzat pel fet que la seva mare el tenia abandonat perquè estava tot el dia a la parròquia, no seria escoltat. Però un ex-Testimoni pot dir-ho i tots sentiran llastima d'ell. Un no pot dir que quan l'obligaven, sent encara una criatura, a anar a la catequesi preparatòria de la primera comunió l'estaven fent un rentat de cervell. Perd un ex-Hare Krisna pot fer acusacions de manipulacions de la ment tot $i$ baver-hi entrat voluntàriameat $i$ ja adult.
} 
invasió de partícules estranyes. Hi ha molt més.

Un missatge se'ns repeteix obsessivament: les sectes són un problema i un perill social. Jo diria que més aviat són un problema i un perill per a la societat, no pas per als seus membres com se'ns vol fer creure. Això que anomenem despectivament sectes han vingut a destarotar un sistema ja muntat. Acceptar-les significaria haver de replantejar-se el repartiment de les esferes de poder $\mathrm{i}$ influències $\mathrm{i}$ renegociar les condicions amb uns nous socis, desconeguts i imprevisibles, que imposen la seva presència. Darrera el sorgiment de l'estereotip del sectarisme aplicat a aquestes institucions invasores hi ha la defensa d'un pacte establert entre poders que fa ja temps varen repartir les seves esferes d'influència i definir la naturalesa de les seves relacions. Les prerrogatives en el terreny de l'espiritualitat les ha tingudes tradicionalment l'Església catolica en la nostra societat. En aparèixer unes institucions que vénen a disputar-li el lloc, les altres instàncies socials, amb les quals està unida per un pacte no explicitat ni escrit enlloc, reaccionen automaticament (i inconscientment segurament): el poder politic promulgant lleis, les famflies creant associacions antisectàries, els mitjans de comunicació difonent una imatge negativa d'aquestes institucions, etc. Enlloc es diu que la institució catolica tingui l'exclusiva en el terreny espiritual, que només ella pugui gestionar l'espiritualitat dels membres de la societat. Tot el contrari: es proclama que existeix una total llibertat en el terreny religiós (d'aquí que es representin les "sectes" com a negocis disfressats de religió negant-los el seu caràcter religiós). Però en realitat, l'Església catolica i les seves institucions catoliques són objecte d'un tracte i una consideració especials... encara que tan sols sigui en el terreny de les representacions (que al capdavall són producte d'una valoració i un judici i es veuen implicades en molts fenòmens i mecanismes socials en els quals poden resultar determinants). Quan un decideix, posem per cas, fer-se benedictr, es considera que està optant per una alternativa de vida espiritual concreta; quan s'uneix a qualsevol d'aquestes institucions definides com a sectes, aquesta decisió se'ns representa de forma molt diferent. La decisió no es relaciona amb inquietuds espirituals personals, sinб amb condicions psiquiques anormals i circumstàncies vitals o ambientals desfavorables que determinen la conducta de l'individu, no es presenta mai com una opció espiritual presa lliurement i per tant digna de tot respecte.

El problema no és que això que anomenem sectes rentin el cervell a les persones. El problema és que ho fan sense que la societat els hagi atorgat aquesta prerrogativa $o$, en el seu defecte, la correspondent patent de cors. Aquesta insolència la paguen carregant amb l'etiqueta desqualificadora de secta $\mathrm{i}$ amb el que aixठ suposa: ser representades com un perill social. L'Església catòlica i l'escola poden adoctrinar criatures sense que es consideri un rentat de cervell; l'exèrcit ho pot també intentar amb part de la població adulta, etc. En aquest cas no es parla de programació; és formació dels membres, adquisició de coneixements, etc.

Es en aquest context que cal analitzar els discursos, la seva naturalesa (desqualificadora 0 reformadora) i el seus continguts (acusacions furibundes o tímidament apuntades només). Tenint com a fons tot aixo, és molt clar com les acusacions es fan o no, es destaquen o se'ls treu importància d'acord amb una plantilla preexistent a la qual els discursants s'adapten. Els fets viscuts i presenciats no serveixen per establir acusacions; les acusacions ja existeixen amb anterioritat, ja estan donades. El que fan les persones és farcir-les recorrent als seus records... en gran part manipulant-los, dissimulant uns i ressaltant-ne d'altres segons convingui, reinterpretant-los... Hi ha plantilles diferents per a cada institucio $\mathrm{i}$ les tenim totes inconscientment presents a l'hora de parlar-ne. Aixo li passa tant a un Testimoni parlant dels catolics com a un catolic parlant dels Testimonis, o a un ex-Testimoni retornat al catolicisme parlant de la seva anterior institució. L'experiència personal molts cops resulta bastant secundària. 